\title{
Efficacy and safety of the artificial pancreas in the paediatric population with type 1 diabetes
}

\author{
Susanna Esposito ${ }^{*}$ Elisa Santi, Giulia Mancini, Francesco Rogari, Giorgia Tascini, Giada Toni, Alberto Argentiero \\ and Maria Giulia Berioli
}

\begin{abstract}
Background: Type 1 diabetes (DM1) is one of the most common chronic diseases in childhood and requires life-long insulin therapy and continuous health care support. An artificial pancreas (AP) or closed-loop system (CLS) have been developed with the aim of improving metabolic control without increasing the risk of hypoglycaemia in patients with DM1. As the impact of APs have been studied mainly in adults, the aim of this review is to evaluate the efficacy and safety of the AP in the paediatric population with DM1.

Main body: The real advantage of a CLS compared to last-generation sensor-augmented pumps is the gradual modulation of basal insulin infusion in response to glycaemic variations (towards both hyperglycaemia and hypoglycaemia), which has the aim of improving the proportion of time spent in the target glucose range and reducing the mean glucose level without increasing the risk of hypoglycaemia. Some recent studies demonstrated that also in children and adolescents an AP is able to reduce the frequency of hypoglycaemic events, an important limiting factor in reaching good metabolic control, particularly overnight. However, the advantages of the AP in reducing hyperglycaemia, increasing the time spent in the target glycaemic range and thus reducing glycated haemoglobin are less clear and require more clinical trials in the paediatric population, in particular in younger children.

Conclusions: Although the first results from bi-hormonal CLS are promising, long-term, head-to-head studies will have to prove their superiority over insulin-only approaches. More technological progress, the availability of more fast-acting insulin, further developments of algorithms that could improve glycaemic control after meals and physical activity are the most important challenges in reaching an optimal metabolic control with the use of the AP in children and adolescents.
\end{abstract}

Keywords: Artificial pancreas, Closed-loop system, Glycated haemoglobin, Sensor-augmented pumps, Type 1 diabetes

\section{Background}

Type 1 diabetes (DM1) is one of the most common chronic diseases in childhood and requires life-long insulin therapy and continuous health care support. To avoid long-term adverse effects of chronically elevated glucose, patients with DM1 should maintain glycaemic levels as near as possible to the physiological range $[1,2]$. Glucose

*Correspondence: susanna.esposito@unimi.it

Pediatric Clinic, Department of Surgical and Biomedical Sciences,

Università degli Studi di Perugia, Piazza Menghini 1, 06129 Perugia, Italy variability has been recently identified as a risk factor for morbidity and mortality in patients with DM1 [3]. The International Society for Pediatric and Adolescent Diabetes (ISPAD) guidelines have recommended a level of glycated haemoglobin $(\mathrm{HbA} 1 \mathrm{c})<7.5 \%$ as an indicator of good metabolic control [4]. To reach this goal, continuous subcutaneous insulin infusion (CSII) combined with continuous glucose monitoring (CGM) is the therapy of choice, especially in young children [5].

In the last few years, two functions that prevent hypoglycaemia by interrupting insulin delivery have been 
created: the low glucose suspend (LGS) and predictive low glucose suspend (PLGS) functions [6, 7]. However, despite the notable progress made, the aim of obtaining good metabolic control is still far from being reached in the majority of patients. One of the reasons is the persistent fear of hypoglycaemia, which leads patients or caregivers to keep blood glucose above target values, especially in younger children [8]. An artificial pancreas (AP) or closed-loop system (CLS) have been developed with the aim of improving metabolic control without increasing the risk of hypoglycaemia in patients with DM1. As the impact of APs has been studied mainly in adults, the aim of this review is to evaluate the efficacy and safety of the AP in the paediatric population with DM1.

\section{Composition of an artificial pancreas (AP)}

An AP is able to automatically adjust insulin delivery rates depending on the interstitial glycaemic level. In the 1970s, the first prototypes of CLSs appeared and could be used only in supervised inpatient settings [9-11]. In the following years, in particular in the last decade, many technological advancements have been made so that today, many portable and sophisticated devices capable of improving glycaemic control are available. Recently, the first CLS was approved by the U.S. Food and Drug Administration (FDA) [12].

Figure 1 shows the composition of AP. An AP is composed of an insulin pump that delivers insulin to subcutaneous tissue and communicates with an interstitial glycaemic sensor. The insulin delivery rate is established by an algorithm that elaborates the sensor's data. Concerning the infusion pump, two subtypes are available: the traditional pumps, with a visible infusion set, and the patch pumps, which are directly adhered to the skin and contain the infusion set inside. The CGM is the component of an AP that detects the interstitial glucose level and provides regular input to the control algorithm. Most of the latest studies have used subcutaneous enzyme glucose sensors with a coupled transmitter for wireless data transmission. The accuracy of a CGM, often expressed as the mean absolute relative difference (MARD), is an important parameter that continues to improve. The latest CGM models have reached an MARD $<10 \%$ and have been approved by the FDA as a reference for insulin dosing [13]. Furthermore, patients' caregivers now have the opportunity to receive alerts in case of hypoglycaemia and hyperglycaemia thanks to the connection of CGM systems to smartphones. Finally, the glucose control algorithm is the central core of an AP and is able to control the glycaemic level. Three major glucose control algorithms have been developed by many research groups [14]:

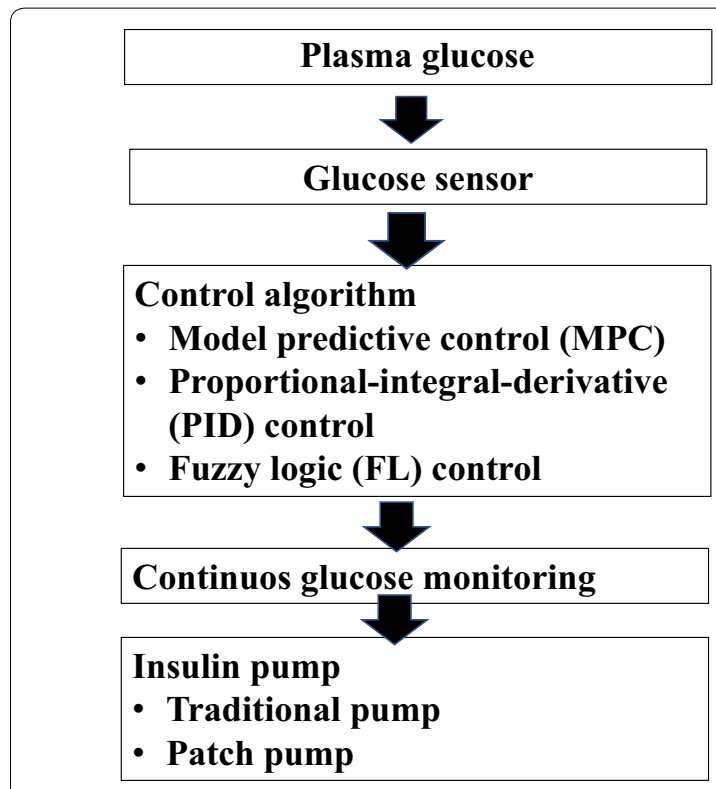

Fig. 1 Composition of artificial pancreas (AP)

model predictive control (MPC) $[15,16]$, proportionalintegral-derivative (PID) $[17,18]$, and fuzzy logic (FL) control [14].

The CLSs that have been investigated differ in many aspects of glycaemic control management. Several clinical trials have studied a bionic AP using a bihormonal pump system including glucagon, in addition to insulin, to avoid hypoglycaemia, while other studies involved a single-hormone AP, which uses insulin only to lower blood glucose and needs the absorption of fast-acting carbohydrates to treat hypoglycaemia. Some devices are hybrid closed-loop systems (HCLSs) that can be used for $24 \mathrm{~h}$ a day or only overnight and require meal announcement by the patients, which consists of the carbohydrate amount or qualitative information (i.e., small, medium or large meal). Other devices, called fully automated CLSs, are able to automatically adjust insulin delivery and establish meal insulin doses without the intervention of the patient. However, few trials have investigated the efficacy of fully automated CLSs, and most of them involved a small number of patients.

\section{Bihormonal artificial pancreas (AP) in the paediatric population}

Some clinical trials have demonstrated the efficacy and safety of both insulin-only [19-25] and bihormonal APs in adults [26-29]. However, there are still few studies on bihormonal AP in the paediatric population, in particular in younger children.

The first clinical trial that used a bihormonal (insulin and glucagon) AP was performed in 2010 by El Khatib et al. [30]. This study demonstrated the safety and efficacy 
of a bihormonal AP in six adult patients with DM1 who used the device for over $48 \mathrm{~h}$ [5]. In 2014, Russell et al. conducted a randomised 5-day crossover study involving a higher number of DM1 patients (20 adults and 32 adolescents) in whom the fully automated bihormonal AP was used in an outpatient setting [29]. Their data showed that an automated bihormonal AP significantly improved glycaemic control by reducing mean blood glucose, increasing the time spent in the target range and reducing hypoglycaemia in both adults and adolescents older than 12 years. The same authors recently reported similar results in 19 preadolescent children with the use of a fully automated bihormonal CLS for 5 days (intervention arm) compared to the use of an SAP for another 5 days (control arm) in two diabetes camps [31]. Furthermore, a recent diabetes camp study, conducted by Haidar et al. compared a bihormonal AP with an insulin-only AP and CSII, demonstrating better glycaemic control and a significant reduction of time spent in hypoglycaemia with the use of the bihormonal system [28].

Overall, the available studies demonstrate the safety and efficacy of the bihormonal AP in paediatric age patients, but a greater number of long-term studies are required to compare the efficacy of bihormonal CLSs with that of single-hormone CLSs. Unfortunately, adolescents are usually studied together with adults, and most of these studies did not distinguish the results in the two groups [32-37]. Some studies comparing HCLSs with sensor-augmented pumps (SAPs) considered adolescents and adults separately and reported that overnight use of a CLS improved time spent in the target glycaemic range and reduced the number of hypoglycaemic events in both groups, without significant differences between the two populations [25]. Other authors showed some differences between the two groups $[29,38]$. Sharifi et al. conducted an at-home, randomized crossover study with 16 adults and 12 adolescents comparing an HCLS to an SAP with the LGS function and reported a reduction of overnight hypoglycaemia with the HCLS, which was more significant in adolescents; they also found an improvement in the percentage of time within the target range $(72-144 \mathrm{mg} / \mathrm{dL})$ only in adults [38]. The different results between Sharifi's study and the other trials [25] could be explained by the different devices used in the control period (i.e., Sharifi's study used an SAP with the LGS function vs an SAP without any threshold suspend function being used in the other trials), the different algorithms analysed and the better glycaemic values of patients before the study [38]. However, the differences found between adults and adolescents could also be explained by the specific characteristics of the adolescent population, such as higher glycaemic variability and insulin resistance, psychological and physiological changes typical of puberty [39] and different eating habits.
In conclusion, further studies are needed to confirm the efficacy and safety of bihormonal AP in the paediatric population. The management of DM1 in adolescents and children has some critical issues, in particular in preschool children, such as very low insulin requirements, unpredictable eating patterns and physical activity and more frequent hypoglycaemia, especially at night. These features must be considered in specific clinical trials in order to demonstrate the advantages of APs in these patients.

\section{Single-hormone artificial pancreas (AP) in the paediatric population}

The first trials in paediatric patients investigating the impact of CLSs on glycaemia have been performed in hospital settings. Two inpatient overnight studies using a single-hormone AP for 2 days demonstrated the safety of closed loop systems in younger children $[40,41]$. In the first trial, Dauber et al. studied ten subjects aged $<7$ years in a randomized controlled cross-over study comparing a CLS with standard open loop pump therapy and demonstrated an improvement of overnight glycaemic control without increasing the incidence of hypoglycaemia with the use of the CLS [40]. In the second trial, Elleri et al. conducted a randomized study that evaluated the use of an HCLS with standard insulin or diluted insulin in children aged 3-6 years [41]. They reported good overnight glycaemic control (glucose was maintained between 70 and $145 \mathrm{mg} / \mathrm{dL}$ for $72 \%$ of the time with standard insulin and for $83 \%$ using diluted insulin) without any hypoglycaemic events requiring treatment [41].

The safety and feasibility of a single-hormone AP was also demonstrated in an outpatient setting, in a randomized cross-over camp study with 30 children (5-9 years old) conducted by Del Favero et al. The authors demonstrated a significant reduction of hypoglycaemic episodes during both day and night (time spent in hypoglycaemia: $6.7 \%$ with open loop vs $2.0 \%$ with CLS; $\mathrm{p}<0.001$ ), but it was associated with a higher mean glucose value with the CLS [42]. A single-hormone AP reduces hypoglycaemia in adolescents and children [34, $35,38,43,44]$, but the real advantage of a CLS compared to last-generation SAPs with LGS and PLGS functions is the possible improvement of the proportion of time spent in the target glucose range, reducing both hyperglycaemia and hypoglycaemia.

The results regarding the benefits of a single-hormone AP on the proportion of time spent within the target range in paediatric patients are conflicting. Some authors have demonstrated the improvement of time within target values [25, 34-36, 44-51], while other studies do not demonstrate any improvement of glycaemic control [30, $37,52]$ or showed only a reduction of hypoglycaemia 
without an increase in time spent in the target range $[38,42]$. On the other hand, in 2015 Thabit et al. demonstrated, in a randomized cross-over study, that a singlehormone AP could be used in free-living conditions for 12 weeks overnight by 25 children and by 33 adults both day and night and that a CLS, compared with SAP therapy, could reduce hypoglycaemia and increase the time spent in the target range. Both populations had a lower mean glucose level with the single-hormone AP compared to the SAP [25].

\section{Limits and future challenges on artificial pancreas (AP)}

Despite the progress made, there are some important limitations that have to be overcome to achieve the ideal AP. First, there is the latency (which is at least $10 \mathrm{~min}$ but may be more in particular situations) between the blood glucose values and interstitial glucose values detected by presently available subcutaneous CGM models [53]. The direct consequence is that a CLS starts the insulin adjustment too late based on glycaemic variation. Second, the fast-acting insulin available absorbs too slowly from subcutaneous tissue, has a delayed onset and has a too long glucose-lowering effect (up to 4-5 h), with an increased risk of late hypoglycaemia, in particular after a meal insulin bolus [53]. Another challenge of an AP is mealtime glycaemic control: if the CLS algorithm varies the insulin infusion only when blood glucose is rising, the glucoselowering effect will begin too late and will not maintain the glycaemic value in the target range. In fact, an HCLS, which was used in the majority of the studies, requires a pre-meal insulin bolus by the patient, usually with the need for $\mathrm{CHO}$ counting to avoid postprandial hyperglycaemia. Even though an HCLS can improve glycaemic control, reduce the time in hypoglycaemia and improve preprandial glucose, patients spend generally $70-75 \%$ of the time in the target range [54], and postprandial glycaemic excursions represent one of the most important limitations to reaching optimal metabolic control in the remaining percentage of time [55].

A recent review by Gingras et al. discussed different methods to overcome the problem of postprandial glycaemic control using a fully automated CLS [55]. Some study groups have experimented with different strategies to reach the goal: Weinzimer et al. used a fully automated CLS with an additional small manual priming bolus of insulin 15 min before meals and demonstrated a reduction of postprandial glucose in 17 adolescents in comparison with a fully automated CLS only [56]. The same authors were the first to test the adjunction of pramlintide to insulin CLS, demonstrating a significant delay in the time to peak prandial blood glucose and a reduction of glycaemic excursions in 8 adolescents and young adults [57].
Another strategy to improve metabolic control and to reduce the burden of carbohydrate counting for patients has been developed by El-Khatib et al. who used an adaptive meal-priming bolus with a bi-hormonal CLS [27]. With this approach, the patient has to select only the meal size (i.e., typical, more than usual or less than usual), and the CLS automatically administers $75 \%$ of the average prandial insulin bolus provided for previous meals at the same time of day. In their randomized controlled trial, El-Khatib et al. demonstrated that adaptive meal-priming boluses could improve the mean glycaemic value without increasing time spent in hypoglycaemia both in adults and in adolescents [27]. Furthermore, Russell showed the efficacy of a bihormonal CLS with adaptive meal-priming boluses in outpatient studies involving both adults and children $[29,52]$.

Unplanned physical activity, particularly in children, is another challenging daily circumstance that hinders good metabolic control in patients using CLS therapy. Recently, Dovc et al. showed an improvement of time spent in the target range after unplanned physical activity in 20 children and adolescents with the use of an HCLS compared to a SAP. However, the small sample size, the short duration of the study and the supervised in-hospital setting represent the most limiting factors of this trial [58]. De Bock et al. conducted an in-clinic observational study in 8 adults and adolescents utilizing an HCLS that included insulin delivery limits [59]. The results demonstrated that the insulin limit strategy was effective in avoiding overnight and exercise-induced hypoglycaemia, even in the presence of an over-reading glucose sensor [59]. Another future prospect is to improve the devices with auxiliary technologies that can provide information about the movement of the patient, such as an accelerometer or a recorder of the heart rate [60,61].

With regard to the bi-hormonal CLS, one of the major limiting factors for long-term use is the poor stability of currently available glucagon formulations and the need for daily replacement of freshly reconstituted glucagon $[62,63]$. However, a more stable glucagon formulation has been developed and is in clinical testing $[64,65]$.

\section{Conclusions}

The real advantage of a CLS compared to last-generation SAPs with LGS and PLGS functions is the gradual modulation of basal insulin infusion in response to glycaemic variations (towards both hyperglycaemia and hypoglycaemia), which has the aim of improving the proportion of time spent in the target glucose range and reducing the mean glucose level without increasing the risk of hypoglycaemia. Many studies showed the efficacy of insulin-only CLS devices in increasing the time spent in normal glycaemia and reducing 
hypoglycaemia and hyperglycaemia compared to SAPs in adults, but there are few studies in the paediatric population, in particular in young children.

However, some recent studies demonstrated that also in children and adolescents an AP is able to reduce the frequency of hypoglycaemic events, an important limiting factor in reaching good metabolic control, particularly overnight. The advantages of the AP in reducing hyperglycaemia, increasing the time spent in the target glycaemic range and thus reducing HbA1c are less clear and require more clinical trials in the paediatric population, in particular in younger children. Although the first results from bi-hormonal CLS are promising, long-term, headto-head studies will have to prove their superiority over insulin-only approaches. More technological progress on CGS, the availability of more fast-acting insulin, further developments of algorithms that could improve glycaemic control after meals and physical activity are the most important challenges in reaching an optimal metabolic control with the use of the AP in children and adolescents.

\begin{abstract}
Abbreviations
AP: artificial pancreas; CGM: continuous glucose monitoring; CLS: closed-loop system; CSII: continuous subcutaneous insulin infusion; DM1: type 1 diabetes; FDA: Food and Drug Administration; FL: fuzzy logic; HbA1c: glycated haemoglobin; HCLs: hybrid closed-loop systems; ISPAD: International Society for Pediatric and Adolescent Diabetes; LGS: Iow glucose suspend; MARD: mean absolute relative difference; MPC: model predictive control; PID: proportionalintegral-derivative; PLGS: predictive low glucose suspend; SAPs: sensoraugmented pumps.
\end{abstract}

\section{Authors' contributions}

ES and GM wrote the first draft of the manuscript; FR, GTa, GT and AA participated in the literature collection and evaluation; MGB and SE supervised and critically revised the manuscript. All authors read and approved the final manuscript.

\section{Acknowledgements}

Not applicable.

\section{Competing interests}

The authors declare that they have no competing interests.

\section{Availability of data and materials}

The data and materials used are included in the review.

\section{Consent for publication}

Not applicable.

\section{Ethics approval and consent to participate}

All the studies mentioned in this review were approved by the Ethics Committee, and written informed consent was obtained by all the participants.

\section{Funding}

None.

\section{Publisher's Note}

Springer Nature remains neutral with regard to jurisdictional claims in published maps and institutional affiliations.

Received: 26 April 2018 Accepted: 23 June 2018

Published online: 28 June 2018

\section{References}

1. Diabetes Control and Complications Trial Research Group, Nathan DM, Genuth S, Lachin J, Cleary P, Crofford O, Davis M, Rand L, Siebert C. The effect of intensive treatment of diabetes on the development and progression of long-term complications in insulin-dependent diabetes mellitus. N Engl J Med. 1993;329:977-86.

2. Nathan DM, Cleary PA, Backlund JY, Genuth SM, Lachin JM, Orchard TJ, Raskin P, Zinman B, Diabetes Control and Complications Trial/Epidemiology of Diabetes Interventions and Complications (DCCT/EDIC) Study Research Group. Intensive diabetes treatment and cardiovascular disease in patients with type 1 diabetes. N Engl J Med. 2005;353:2643-53.

3. Hsu CR, Chen YT, Sheu WH. Glycemic variability and diabetes retinopathy: a missing link. J Diabetes Complications. 2015;29:302-6.

4. de Beaufort C, Rewers MJ, Pillay K, Craig ME, Hanas R, Acerini CL, Maahs DM, International Society for Pediatric and Adolescent Diabetes: ISPAD Clinical Practice Consensus Guidelines 2014. Assessment and monitoring of glycemic control in children and adolescents with diabetes. Pediatr Diabetes. 2014;2014(15):102-14.

5. Bergenstal RM, Tamborlane WV, Ahmann A, Buse JB, Dailey G, Davis SN, Joyce C, Perkins BA, Welsh JB, Willi SM, Wood MA, STAR 3 Study Group. Effectiveness of sensor-augmented insulin-pump therapy in type 1 diabetes. N Engl J Med. 2010;363:311-20.

6. Ly TT, Nicholas JA, Retterath A, Lim EM, Davis EA, Jones TW. Effect of sensor-augmented insulin pump therapy and automated insulin suspension vs standard insulin pump therapy on hypoglycemia in patients with type 1 diabetes. JAMA. 2013;310:1240.

7. Buckingham BA, Raghinaru D, Cameron F, Bequette BW, Chase HP, Maahs DM, Slover R, Wadwa RP, Wilson DM, Ly T, Aye T, Hramiak I, Clarson C, Stein R, Gallego PH, Lum J, Sibayan J, Kollman C, Beck RW, In Home Closed Loop Study Group. Predictive low-glucose insulin suspension reduces duration of nocturnal hypoglycemia in children without increasing ketosis. Diabetes Care. 2015;38:1197-204.

8. Cryer PE. The barrier of hypoglycemia in diabetes. Diabetes. 2008;57:3169-76.

9. Marliss EB, Murray FT, Stokes EF, Zinman B, Nakhooda AF, Denoga A, Leibel BS, Albisser AM. Normalization of glycemia in diabetics during meals with insulin and glucagon delivery by the artificial pancreas. Diabetes. 1977;26:663-72.

10. Albisser AM, Leibel BS, Ewart TG, Davidovac Z, Botz CK, Zingg W, Schipper $\mathrm{H}$, Gander R. Clinical control of diabetes by the artificial pancreas. Diabetes. 1974;23:397-404.

11. Mirouze J, Selam JL, Pham TC, Cavadore D. Evaluation of exogenous insulin homoeostasis by the artificial pancreas in insulin-dependent diabetes. Diabetologia. 1977;13:273-8.

12. Voelker R. Artificial pancreas is approved. JAMA. 2016;316:1957.

13. Food and Drug Administration. FDA advisory panel votes to recommend non-adjunctive use of Dexcom G5 Mobile CGM. Diabetes Technol Ther. 2016;18:512-6.

14. Doyle FJ, Huyett LM, Lee JB, Zisser HC, Dassau E. Closed-loop artificial pancreas systems: engineering the algorithms. Diabetes Care. 2014:37:1191-7.

15. Hovorka R, Canonico V, Chassin LJ, Haueter U, Massi-Benedetti M, Orsini Federici M, Pieber TR, Schaller HC, Schaupp L, Vering T, Wilinska ME. Nonlinear model predictive control of glucose concentration in subjects with type 1 diabetes. Physiol Meas. 2004;25:905-20.

16. Schmidt S, Boiroux D, Duun-Henriksen AK, Frøssing L, Skyggebjerg O, Jørgensen JB, Poulsen NK, Madsen H, Madsbad S, Nørgaard K. Model-based closed-loop glucose control in type 1 diabetes: the DiaCon experience. $J$ Diabetes Sci Technol. 2013;7:1255-64.

17. Steil GM, Rebrin K, Janowski R, Darwin C, Saad MF. Modeling beta-cell insulin secretion-implications for closed-loop glucose homeostasis. Diabetes Technol Ther. 2003;5:953-64.

18. Steil GM, Palerm CC, Kurtz N, Voskanyan G, Roy A, Paz S, Kandeel FR. The effect of insulin feedback on closed loop glucose control. J Clin Endocrinol Metab. 2011;96:1402-8.

19. Kropff J, Del Favero S, Place J, Toffanin C, Visentin R, Monaro M, Messori M, Di Palma F, Lanzola G, Farret A, Boscari F, Galasso S, Magni P, Avogaro A, Keith-Hynes P, Kovatchev BP, Bruttomesso D, Cobelli C, DeVries JH, Renard E, Magni L, AP@home consortium. 2-month evening and night closedloop glucose control in patients with type 1 diabetes under free-living 
conditions: a randomised crossover trial. Lancet Diabetes Endocrinol. 2015;3:939-47.

20. Thabit $H$, Lubina-Solomon A, Stadler M, Leelarathna L, Walkinshaw $E$, Pernet A, Allen JM, Iqbal A, Choudhary P, Kumareswaran K, Nodale M, Nisbet C, Wilinska ME, Barnard KD, Dunger DB, Heller SR, Amiel SA, Evans ML, Hovorka R. Home use of closed-loop insulin delivery for overnight glucose control in adults with type 1 diabetes: a 4-week, multicentre, randomised crossover study. Lancet Diabetes Endocrinol. 2014;2:701-9.

21. Leelarathna L, Dellweg S, Mader JK, Allen JM, Benesch C, Doll W, Ellmerer M, Hartnell S, Heinemann L, Kojzar H, Michalewski L, Nodale M, Thabit H, Wilinska ME, Pieber TR, Arnolds S, Evans ML, Hovorka R, AP@home Consortium. Day and night home closed-loop insulin delivery in adults with type 1 dDiabetes: three-center randomized crossover study. Diabetes Care. 2014;37:1931-7.

22. Renard E, Farret A, Kropff J, Bruttomesso D, Messori M, Place J, Visentin R, Calore R, Toffanin C, Di Palma F, Lanzola G, Magni P, Boscari F, Galasso S, Avogaro A, Keith-Hynes P, Kovatchev B, Del Favero S, Cobelli C, Magni L, DeVries JH, AP@home Consortium. Day-and-night closed-loop glucose control in patients with type 1 diabetes under free-living conditions: results of a single-arm 1-month experience compared with a previously reported feasibility study of evening and night at home. Diabetes Care. 2016;39:1151-60.

23. Anderson SM, Raghinaru D, Pinsker JE, Boscari F, Renard E, Buckingham BA, Nimri R, Doyle FJ 3rd, Brown SA, Keith-Hynes P, et al. Multinational home use of closed-loop control is safe and effective. Diabetes Care. 2016;39:1143-50.

24. Del Favero S, Place J, Kropff J, Messori M, Keith-Hynes P, Visentin $R$ Monaro M, Galasso S, Boscari F, Toffanin C, Di Palma F, Lanzola G, Scarpellini S, Farret A, Kovatchev B, Avogaro A, Bruttomesso D, Magni L, DeVries $\mathrm{JH}$, Cobelli C, Renard E, AP@home Consortium. Multicenter outpatient dinner/overnight reduction of hypoglycemia and increased time of glucose in target with a wearable artificial pancreas using modular model predictive control in adults with type 1 diabetes. Diabetes Obes Metab. 2015;17:468-76.

25. Thabit H, Tauschmann M, Allen JM, Leelarathna L, Hartnell S, Wilinska ME, Acerini CL, Dellweg S, Benesch C, Heinemann L, Mader JK, Holzer M, Kojzar H, Exall J, Yong J, Pichierri J, Barnard KD, Kollman C, Cheng P, Hindmarsh PC, Campbell FM, Arnolds S, Pieber TR, Evans ML, Dunger DB, Hovorka R. Home use of an artificial beta cell in type 1 diabetes. N Engl J Med. 2015;373:2129-40.

26. Haidar A, Legault L, Dallaire M, Alkhateeb A, Coriati A, Messier V, Cheng P, Millette M, Boulet B, Rabasa-Lhoret R. Glucose-responsive insulin and glucagon delivery (dual-hormone artificial pancreas) in adults with type 1 diabetes: a randomized crossover controlled trial. CMAJ. 2013;185:297-305.

27. El-Khatib FH, Russell SJ, Magyar KL, Sinha M, McKeon K, Nathan DM, Damiano ER. Autonomous and continuous adaptation of a bihormonal bionic pancreas in adults and adolescents with type 1 diabetes. J Clin Endocrinol Metab. 2014;99:1701-11.

28. Haidar A, Legault L, Messier V, Mitre TM, Leroux C, Rabasa-Lhoret R. Comparison of dual-hormone artificial pancreas, single-hormone artificial pancreas, and conventional insulin pump therapy for glycaemic control in patients with type 1 diabetes: an open-label randomised controlled crossover trial. Lancet Diabetes Endocrinol. 2015;3:17-26.

29. Russell SJ, El-Khatib FH, Sinha M, Magyar KL, McKeon K, Goergen LG, Balliro C, Hillard MA, Nathan DM, Damiano ER. Outpatient glycemic control with a bionic pancreas in type 1 diabetes. N Engl J Med. 2014;371:313-25.

30. El-Khatib FH, Russell SJ, Nathan DM, Sutherlin RG, Damiano ER. A bihormonal closed-loop artificial pancreas for type 1 diabetes. Sci Transl Med. 2010;2:27.

31. Russell SJ, Hillard MA, Balliro C, Magyar KL, Selagamsetty R, Sinha M, Grennan K, Mondesir D, Ekhlaspour L, Zheng H, Damiano ER, El-Khatib FH. Day and night glycaemic control with a bionic pancreas versus conventional insulin pump therapy in preadolescent children with type 1 diabetes: a randomised crossover trial. Lancet Diabetes Endocrinol. 2016;4:233-43.

32. Ly TT, Roy A, Grosman B, Shin J, Campbell A, Monirabbasi S, Liang B, von Eyben R, Shanmugham S, Clinton P, Buckingham BA. Day and night closed-loop control using the integrated medtronic hybrid closed-loop system in type 1 diabetes at diabetes camp. Diabetes Care. 2015;38:1205-11.
33. Haidar A, Rabasa-Lhoret R, Legault L, Lovblom LE, Rakheja R, Messier V, D'Aoust É, Falappa CM, Justice T, Orszag A, Tschirhart H, Dallaire M, Ladouceur M, Perkins BA. Single-and dual-hormone artificial pancreas for overnight glucose control in type 1 diabetes. J Clin Endocrinol Metab. 2016;101:214-23.

34. Nimri R, Muller I, Atlas E, Nimri R, Muller I, Atlas E. MD-logic overnight control for 6 weeks of home use in patients with type 1 diabetes: randomized crossover trial. Diabetes Care. 2014;37:3025-32.

35. O'Grady MJ, Retterath AJ, Keenan DB, Kurtz N, Cantwell M, Spital G, Kremliovsky MN, Roy A, Davis EA, Jones TW, Ly TT. The use of an automated, portable glucose control system for overnight glucose control in adolescents and young adults with type 1 diabetes. Diabetes Care. 2012;35:2182-7.

36. Thabit H, Elleri D, Leelarathna L, Allen J, Lubina-Solomon A, Stadler M, Walkinshaw E, lqbal A, Choudhary P, Wilinska M, Barnard K, Heller S, Amiel S, Evans M, Dunger D, Hovorka R. Unsupervised home use of an overnight closed-loop system over 3-4 weeks: a pooled analysis of randomized controlled studies in adults and adolescents with type 1 diabetes. Diabetes Obes Metab. 2015;17:452-8.

37. de Bock MI, Roy A, Cooper MN, Dart JA, Berthold CL, Retterath AJ, Freeman KE, Grosman B, Kurtz N, Kaufman F, Jones TW, Davis EA. Feasibility of outpatient 24-hour closed-loop insulin delivery. Diabetes Care. 2015;38:e186-7.

38. Sharifi A, De Bock MI, Jayawardene D, Loh MM, Horsburgh JC, Berthold CL, Paramalingam N, Bach LA, Colman PG, Davis EA, Grosman B, Hendrieckx C, Jenkins AJ, Kumareswaran K, Kurtz N, Kyoong A, Maclsaac RJ, Speight J, Trawley S, Ward GM, Roy A, Jones TW, O'Neal DN. Glycemia, treatment satisfaction, cognition, and sleep quality in adults and adolescents with type 1 diabetes when using a closed-loop system overnight versus sensor-augmented pump with low-glucose suspend function: a randomized crossover study. Diabetes Technol Ther. 2016;18:772-83.

39. Acerini CL, Williams RM, Dunger DB, Acerini L, Williams M, Dunger B. Metabolic impact of puberty on the course of type 1 diabetes. Diabetes Metab. 2001;27:S19-25.

40. Dauber A, Corcia L, Safer J, Agus MSD, Einis S, Steil GM. Closed-loop insulin therapy improves glycemic control in children aged $<7$ years. A randomized controlled trial. Diabetes Care. 2013;36:222-7.

41. Elleri D, Allen JM, Tauschmann M, El-Khairi R, Benitez-Aguirre P, Acerini CL, Dunger DB, Hovorka R. Feasibility of overnight closed-loop therapy in young children with type 1 diabetes aged 3-6 years: comparison between diluted and standard insulin strength. BMJ Open Diabetes Res Care. 2014;2:e000040.

42. Del Favero S, Boscari F, Messori M, Rabbone I, Bonfanti R, Sabbion A, lafusco D, Schiaffini R, Visentin R, Calore R, Moncada YL, Galasso S, Galderisi A, Vallone V, Di Palma F, Losiouk E, Lanzola G, Tinti D, Rigamonti A, Marigliano M, Zanfardino A, Rapini N, Avogaro A, Chernavvsky D, Magni L, Cobelli C, Bruttomesso D. Randomized summer camp crossover trial in 5to 9-year-old children: outpatient wearable artificial pancreas is feasible and safe. Diabetes Care. 2016;39:1180-5.

43. Hovorka R, Allen JM, Elleri D, Chassin L, Harris J, Xing D, Kollman C, Hovorka T, Larsen AM, Nodale M, De Palma A, Wilinska ME, Acerini CL, Dunger DB. Manual closed-loop insulin delivery in children and adolescents with type 1 diabetes: a phase 2 randomised crossover trial. Lancet. 2010;375:743-51.

44. Ly TT, Keenan DB, Roy A, Han J, Grosman B, Cantwell M, Kurtz N, von Eyben R, Clinton P, Wilson DM, Buckingham BA. Automated overnight closed-loop control using a proportional-integral-derivative algorithm with insulin feedback in children and adolescents with type 1 diabetes at diabetes camp. Diabetes Technol Ther. 2016;18:377-84.

45. Phillip M, Battelino T, Atlas E, Kordonouri O, Bratina N, Miller S, Biester T, Stefanija MA, Muller I, Nimri R, Danne T. Nocturnal glucose control with an artificial pancreas at a diabetes camp. N Engl J Med. 2013;368:824-33.

46. Hovorka R, Elleri D, Thabit H, Allen JM, Leelarathna L, El-Khairi R, Kumareswaran K, Caldwell K, Calhoun P, Kollman C, Murphy HR, Acerini CL, Wilinska ME, Nodale M, Dunger DB. Overnight closed-loop insulin delivery in young people with type 1 diabetes: a free-living, randomized clinical trial. Diabetes Care. 2014;37:1204-11.

47. Ly TT, Breton MD, Keith-Hynes P, De Salvo D, Clinton P, Benassi K, Mize B, Chernavvsky D, Place J, Wilson DM, Kovatchev BP, Buckingham BA. Overnight glucose control with an automated, unified safety system in 
children and adolescents with type 1 diabetes at diabetes camp. Diabetes Care. 2014;37:2310-6.

48. Ly TT, Weinzimer SA, Maahs DM, Sherr JL, Roy A, Grosman B, Cantwell M, Kurtz N, Carria L, Messer L, von Eyben R, Buckingham BA. Automated hybrid closed-loop control with a proportional-integral-derivative based system in adolescents and adults with type 1 diabetes: individualizing settings for optimal performance. Pediatr Diabetes. 2017:18:348-55.

49. Tauschmann M, Allen JM, Wilinska ME, Tauschmann M, Allen JM, Wilinska ME. Day-and-night hybrid closed-loop insulin delivery in adolescents with type 1 diabetes: a free-living, randomized clinical trial. Diabetes Care. 2016:39:1168-74.

50. Elleri D, Allen JM, Kumareswaran K, Leelarathna L, Nodale M, Caldwell K, Cheng P, Kollman C, Haidar A, Murphy HR, Wilinska ME, Acerini CL, Dunger DB, Hovorka R. Closed-loop basal insulin delivery over 36 hours in adolescents with type 1 diabetes: randomized clinical trial. Diabetes Care. 2013;36:838-44.

51. Ly TT, Buckingham BA, DeSalvo DJ, Shanmugham S, Satin-Smith M, DeBoer MD, Oliveri MC, Schertz E, Breton MD, Cherñavvsky DR. Day-andnight closed-loop control using the unified safety system in adolescents with type 1 diabetes at camp. Diabetes Care. 2016:39:e106-7.

52. Oron T, Farfel A, Muller I, Miller S, Atlas E, Nimri R, Phillip M. A remote monitoring system for artificial pancreas support is safe, reliable, and user friendly. Diabetes Technol Ther. 2014;16:699-705.

53. Home PD. The pharmacokinetics and pharmacodynamics of rapid-acting insulin analogues and their clinical consequences. Diabetes Obes Metab. 2012;14:780-8.

54. Thabit $\mathrm{H}$, Hovorka R. Coming of age: the artificial pancreas for type 1 diabetes. Diabetologia. 2016;59:1795-805.

55. Gingras V, Taleb N, Roy-Fleming A, Legault L, Rabasa-Lhoret R. The challenges of achieving postprandial glucose control using closedloop systems in patients with type 1 diabetes. Diabetes Obes Metab. 2018;20:245-56.

56. Weinzimer SA, Steil GM, Swan KL, Dziura J, Kurtz N, Tamborlane WV. Fully automated closed-loop insulin delivery versus semiautomated hybrid control in pediatric patients with type 1 diabetes using an artificial pancreas. Diabetes Care. 2008;31:934-9.
57. Weinzimer SA, Sherr JL, Cengiz E, Kim G, Ruiz JL, Carria L, Voskanyan G, Roy A, Tamborlane WV. Effect of pramlintide on prandial glycemic excursions during closed-loop control in adolescents and young adults with type 1 diabetes. Diabetes Care. 2012;35:1994-9.

58. Dovc K, Macedoni M, Bratina N, Lepej D, Nimri R, Atlas E, Muller I, Kordonouri O, Biester T, Danne T, Phillip M, Battelino T. Closed-loop glucose control in young people with type 1 diabetes during and after unannounced physical activity: a randomised controlled crossover trial Abbreviations HRM Heart rate monitor IQR Interquartile range ISPAD International Society for paediatric and adolescent diabetes SAP Sensor-augmented insulin pump SMBG Self-monitoring of blood glucose. Diabetologia. 2017:60:2157-67.

59. de Bock M, Dart J, Roy A, de Bock M, Dart J, Roy A. Exploration of the performance of a hybrid closed loop insulin delivery algorithm that includes insulin delivery limits designed to protect against hypoglycemia. J Diabetes Sci Technol. 2017;11:68-73.

60. Heinemann L, Benesch C, DeVries JH, AP@home Consortium. AP@home. J Diabetes Sci Technol. 2016;10:950-8.

61. Turksoy K, Paulino TML, Zaharieva DP, Yavelberg L, Jamnik V, Riddell MC, Cinar A. Classification of physical activity. J Diabetes Sci Technol. 2015;9:1200-7.

62. Hanazaki K, Munekage M, Kitagawa H, Yatabe T, Munekage E, Shiga M, Maeda H, Namikawa T. Current topics in glycemic control by wearable artificial pancreas or bedside artificial pancreas with closed-loop system. J Artif Organs. 2016;19:209-18.

63. Taleb N, Haidar A, Messier V, Gingras V, Legault L, Rabasa-Lhoret R. Glucagon in artificial pancreas systems: potential benefits and safety profile of future chronic use. Diabetes Obes Metab. 2017;19:13-23.

64. Pohl R, Li M, Krasner A, De Souza E. Development of stable liquid glucagon formulations for use in artificial pancreas. J Diabetes Sci Technol. 2015:9:8-16.

65. Newswanger B, Ammons S, Phadnis N, Ward WK, Castle J, Campbell RW, Prestrelski SJ. Development of a highly stable, nonaqueous glucagon formulation for delivery via infusion pump systems. J Diabetes Sci Technol. 2015:9:24-33.
Ready to submit your research? Choose BMC and benefit from:

- fast, convenient online submission

- thorough peer review by experienced researchers in your field

- rapid publication on acceptance

- support for research data, including large and complex data types

- gold Open Access which fosters wider collaboration and increased citations

- maximum visibility for your research: over $100 \mathrm{M}$ website views per year

At BMC, research is always in progress.

Learn more biomedcentral.com/submissions 